\title{
Elizabethkingia meningoseptica and Contact Lens Use
}

\section{Elizabethkingia meningoseptica e o Uso de Lentes de Contato}

João N. BEATO $\rrbracket^{1}$, Maria J ESPINAR ${ }^{2,3}$, Luís FIGUEIRA ${ }^{1,4}$, Yuliana O. EREMINA ${ }^{3}$, Manuela RIBEIRO ${ }^{3}$, Raúl MOREIRA $^{1}$, Fernando FALCÃO-REIS ${ }^{1,5}$

Acta Med Port 2016 Apr;29(4):287-289 - http://dx.doi.org/10.20344/amp.7048

\begin{abstract}
A47-year-old man presented to our emergency department complaining of acute ocular pain and redness of his left eye. Ophthalmological antecedents included use of semi-rigid contact lens and primary open-angle glaucoma. Slit-lamp examination revealed a small central corneal ulcer associated with stromal inflammatory infiltrate. Scraping from the corneal ulcer was positive for Elizabethkingia meningoseptica. He was empirically treated with topical $0.5 \%$ levofloxacin and $0.3 \%$ gentamicin, and five weeks later the infection had resolved. In this case report we describe the uncommon association between contact lens and Elizabethkingia meningoseptica. Despite possible serious complications associated with this atypical agent, prompt diagnosis and adequate treatment lead to good visual prognosis.
\end{abstract}

Keywords: Contact Lenses; Corneal Ulcer; Chryseobacterium; Flavobacteriaceae Infections; Keratitis.

\section{RESUMO}

Doente de 47 anos, sexo masculino, recorreu ao serviço de urgência por início súbito de dor ocular e hiperemia conjuntival no olho esquerdo. Os antecedentes oftalmológicos incluíam o uso de lente de contacto semi-rígida e glaucoma primário de ângulo aberto. O exame na lâmpada de fenda revelou uma pequena úlcera de córnea central associada a infiltrado inflamatório estromal. A zaragatoa da base da úlcera de córnea permitiu a identificação de colónias de Elizabethkingia meningoseptica. O doente foi empiricamente tratado com levofloxacina colírio $0,5 \%$ e pomada de gentamicina $0,3 \%$, tendo a infecção resolvido após cinco semanas. Neste caso clínico, descrevemos a associação incomum entre lentes de contacto e Elizabethkingia meningoseptica. Apesar das possíveis complicações graves relacionadas com este agente etiopatogénico, o diagnóstico rápido e tratamento adequado permitiram um bom prognóstico visual.

Palavras-chave: Chryseobacterium; Infecções por Flavobacteriaceae; Lentes de Contacto; Queratite; Úlcera de Córnea.

\section{INTRODUCTION}

Elizabethkingia meningoseptica, formerly known as Flavobacterium meningosepticum, belongs to the family of Flavobacteriae. It is widely distributed in different geographical areas and habitats, but not in human microflora. ${ }^{1}$ We describe the first clinical case of corneal ulcer caused by $E$. meningoseptica registered in Europe.

\section{CASE REPORT}

A 47-year-old caucasian man presented to the ophthalmology emergency department of the Centro Hospitalar São João (Porto, Portugal) in August 2013 with a two day history of increasing pain and redness of his left eye (OS). He had no relevant systemic antecedents but he was regularly followed in the outpatient department due to primary open-angle glaucoma (treated with topical latanoprost, brimonidine, timolol and brinzolamide) and pathological myopia. Right eye visual acuity (VA) was hand movement due to terminal glaucoma. Ophthalmological antecedents also included the use of semi-rigid contact lens in the left eye. On our first examination, left eye visual acuity was 20/32 and biomicroscopy revealed a stromal keratitis with ill-defined borders and a small epithelial

defect measuring $0.5 \mathrm{~mm} \times 0.5 \mathrm{~mm}$ (Fig. 1). Scrapings from corneal ulcer and lower conjunctival fornix were sent for microbiological testing and topical empiric treatment $(0,5 \%$ levofloxacin drops $1 / 1$ hour and 0,3\% gentamicin ointment $4 / 4$ hours for 3 days) was prescribed. Evaluation 72 hours later showed loose re-epithelialization of the ulcer and

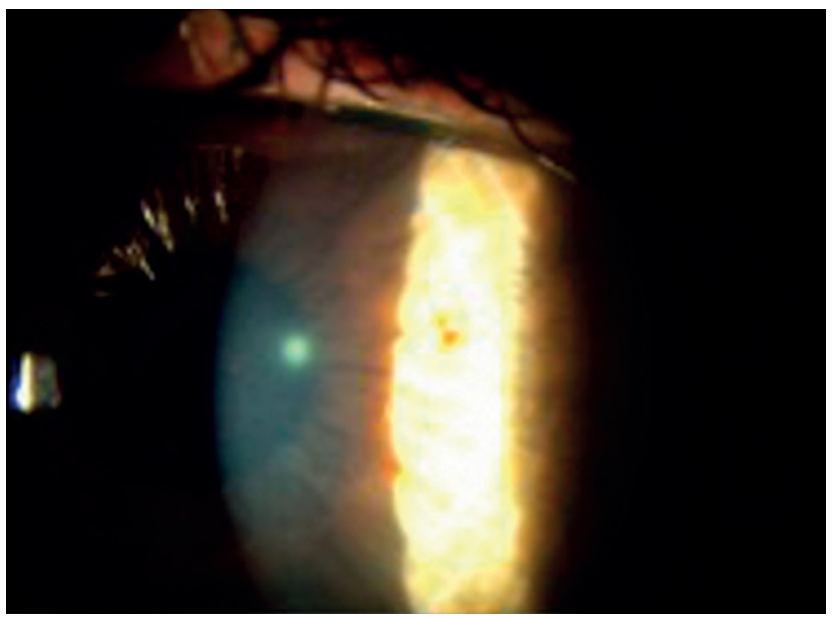

Figure 1 - Silt-lamp examination revealed a central corneal ulcer $0.5 \times 0.5 \mathrm{~mm}$ with stromal inflammatory infiltrate

1. Department of Ophthalmology. São João Hospital Centre. Porto. Portugal.

2. Department of Microbiology. Faculty of Medicine. University of Porto. Porto. Portugal.

3. Department of Clinical Pathology. São João Hospital Centre. Porto. Portugal.

4. Department of Pharmacology and Therapeutics. Faculty of Medicine. University of Porto. Porto. Portugal.

5. Department of Sense Organs. Faculty of Medicine. University of Porto. Porto. Portugal

$\square$ Autor correspondente: João N. Beato. joao.nuno.beato@gmail.com

Recebido: 02 de outubro de 2015 - Aceite: 24 de janeiro de 2016 | Copyright @ Ordem dos Médicos 2016 


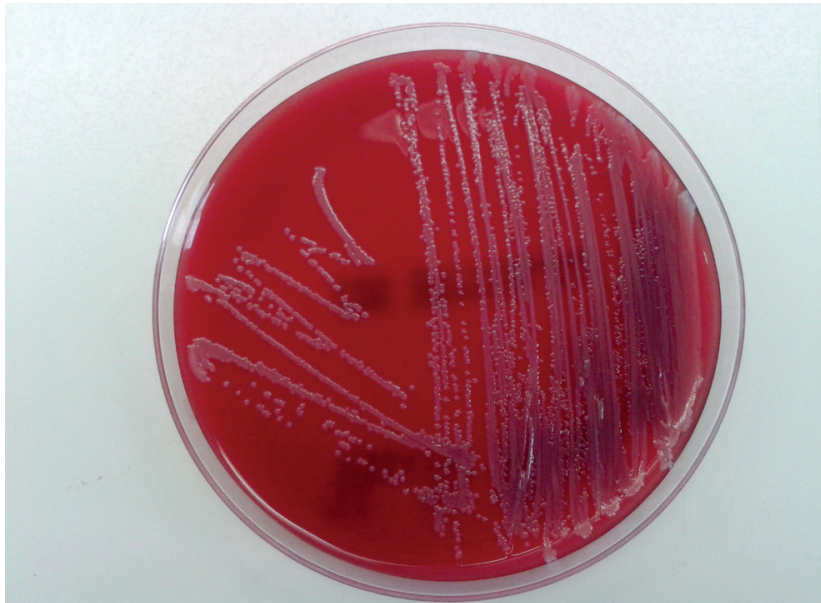

Figure 2 - Growth of yellowish colonies in blood sheep agar medium (24 hours after incubation with $\mathrm{CO}_{2}$ atmosphere)

a micro-abscess. At this time, we decided to remove the epithelium and the infected stroma.

Bacterial cultures of the conjunctival swab were negative. However, culture of the corneal ulcer showed prominent growth of yellowish colonies on $5 \%$ sheep blood agar plates (Fig. 2) and no growth on MacConkey agar, a selective media for Gram negative bacilli. The isolate was subsequently identified as Elizabethkingia meningoseptica using a matrix-assisted laser-desorption/ionisation time-offlight mass spectrometry (VITEK MS) and VITEK2 system (GN Card). Conventional methods like Gram stain, oxidase, catalase and indole tests were adicionally performed (Fig. 3). According to guidelines of Clinical and Laboratory Standards Institute, minimum inhibitory concentrations (MIC) were determined by E-test, presenting bacteria susceptibility to levofloxacin, trimethoprim-sulfamethoxazole, gentamicin, tigecycline, vancomycin and resistance to tobramycin, imipenem, ceftazidime and colistin.

After one week, a small central leucoma developed with no evidence of epithelial defect. Levofloxacin drops and gentamicin ointment were tapered and we decided to add $0.1 \%$ fluorometholone $8 / 8 \mathrm{~h}$. Two weeks later the patient had no complaints, yet slit-lamp examination revealed superficial punctate keratitis associated with the central leucoma. The patient completed a tapering course of the antibiotics and 5 weeks after our initial observation the infection was totally healed.

\section{DISCUSSION}

Ocular infections caused by Elizabethkingia meningoseptica are extremely rare and frequently associated with local predisposing conditions. Ocular surgery (penetrating keratoplasty $)^{2}$ and trauma, ${ }^{3-5}$ contact lens use $^{6,7}$ or ocular surface disorders ${ }^{8-10}$ have been identified as possible risk factors. In our patient, combination of long term topical ocular hypotensive drugs and contact lens use might have created the perfect environment for Elizabethkingia to grow. Both conditions are known to significantly change ocular surface and predispose to

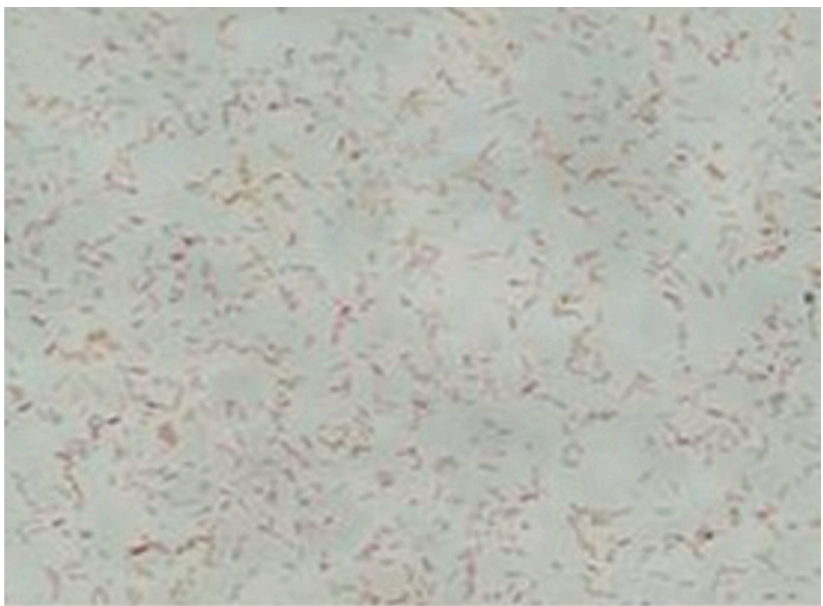

Figure 3 - Gram negative rods, gram stain (x1000)

corneal infection.

Contact lens and its case were not available for examination, so it was not possible to ascertain the origin of contamination. However, it is the most probable etiology since Elizabethkingia can survive in chlorine-treated municipal water used to wash contact lens case. ${ }^{11}$

Our case report highlights the importance of correct microbiological diagnosis in patients with predisposing factors for corneal infections. Tipically, Elizabethkingia infections have a poor prognosis due to its unusual resistance patterns to routinely used antibiotics (betalactams, aminoglycosides and chloramphenicol).12 However, a correct microbiological diagnosis and adequate treatment can lead to good clinical response and minor sequelae as in this case.

\section{Meeting presentation}

"24th European Congress of Clinical Microbiology and Infectious Diseases", Barcelona, Spain, May 10-13 2014.

"5th Congress of the European Society of Cornea and Ocular Surface disease Specialists-EUCORNEA", London, United Kingdom, September 12-13 2014.

"Congress of European Society of Ophthalmology", Vienna, Austria, June 6-9 2015.

\section{PROTECTION OF HUMANS AND ANIMALS}

The authors declare that the procedures were followed according to the regulations established by the Clinical Research and Ethics Committee and to the Helsinki Declaration of the World Medical Association.

\section{DATA CONFIDENTIALITY}

The authors declare having followed the protocols in use at their working center regarding patient's data publication.

\section{CONFLICTS OF INTEREST}

The authors declare that there are no conflicts of interest. 


\section{FUNDING SOURCES}

This study was supported by the Ophthalmology and
Clinical Pathology departments of Centro Hospitalar São João, Porto, Portugal.

\section{REFERENCES}

1. Hoque SN, Graham J, Kaufmann ME, Tabaqchali S. Chryseobacterium (Flavobacterium) meningosepticum outbreak associated with colonization of water taps in a neonatal intensive care unit. J Hosp Infect. 2001;47:188-92.

2. LeFrancois M, Baum JL. Flavobacterium endophthalmitis following keratoplasty. Use of a tissue culture medium-stored cornea. Arch Ophthalmol. 1976;94:1907-9.

3. Essex RW, Charles PG, Allen PJ. Three cases of post-traumatic endophthalmitis caused by unusual bacteria. Clin Exp Ophthalmol. 2004;32:445-7.

4. Connell PP, Wickremasinghe S, Devi U, Waters Mj, Allen Pj. Selfinduced Elizabethkingia meningoseptica endophthalmitis: a case report. J Med Case Rep 2011;5:303.

5. Erdem E, Abdurrahmanoglu S, Kibar F, Yagmur M, Koksal F, Ersoz R. Posttraumatic keratitis caused by Elizabethkingia meningosepticum. Eye Contact Lens. 2013;39:361-3.

6. Yang YS, Chun JW, Koh JW. Keratitis with Elizabethkingia meningoseptica occurring after contact lens wear: a case report. Korean

J Ophthalmol. 2013;27:133-6.

7. Ray M, Lim DK. A rare polymicrobial keratitis involving Chryseobacterium meningosepticum and Delftia acidovorans in a cosmetic contact lens wearer. Eye Contact Lens. 2013;39:192-3.

8. Bloom AH, Perry HD, Donnenfeld ED, Davis RG. Chryseobacterium meningosepticum keratitis. Am J Ophthalmol. 2003;136:356-7.

9. Bucci FA, Jr., Holland EJ. Flavobacterium meningosepticum keratitis successfully treated with topical trimethoprim-sulfamethoxazole. Am J Ophthalmol. 1991;111:116-8.

10. Li EY, Jhanji V. Massive lipid keratopathy after Elizabethkingia meningosepticum keratitis. Cont Lens Anterior Eye. 2014;37:55-6.

11. Wu YT, Willcox M, Zhu H, Stapleton F. Contact lens hygiene compliance and lens case contamination: a review. Cont Lens Anterior Eye. 2015;38:307-16.

12. Ratnamani MS, Rao R. Elizabethkingia meningoseptica: Emerging nosocomial pathogen in bedside hemodialysis patients. Indian J Crit Care Med. 2013;17:304-7. 